\title{
Grey Water Recycle System for a University Building: A Case Study in Thailand
}

\author{
Wannawit Taemthong and Phongphiphat Phenphon
}

\begin{abstract}
This research investigated three alternatives in recycling grey water from washbasin for reusing in toilet flushing system. Grey water were collected from all washbasins from 2nd floor to 9 th floor of a 9 stories university building. The water were treated in three experiment systems in order to reuse in flushing systems such as men urinals and toilets. A recommended grey water treatment system is a set of a sedimentation tank, an aeration tank, a sand and carbon filtering tank, and a final sedimentation tank. Water quality after the treatment has $\mathrm{SS}, \mathrm{BOD}_{5}$, and turbidity of $1.67 \mathrm{mg} / \mathrm{l}$, $3.33 \mathrm{mg} / \mathrm{l}$, and 3.33 NTU, respectively. Fecal coliform bacteria and E.Coli were not found in the treated water. Efficiency in reducing $\mathrm{SS}, \mathrm{BOD}_{5}$, and turbidity are $90 \%, 78 \%$, and $75 \%$, respectively. In conclusion, grey water can be recycled and reused in flushing systems to use water more efficiently in buildings.
\end{abstract}

Index Terms-Grey water, recycle, wash basin, and water efficiency.

\section{INTRODUCTION}

Grey water is the water which is slightly contaminated by human activities and may be reused after suitable treatment [1]. It arises from domestic washing operations such as washbasin, shower, bath, kitchen sink, and washing machine, but exclude black water sources from toilet and urinal [1], [2] Using recycle grey water could promote a preservation of high quality fresh water supply and reduce pollutant in the environment and thus reducing potable water ranging from $28.7 \%$ to $34.8 \%$ [1], [3]. On site water treatment and reuse of grey water are the most interesting issue for wastewater recycling [4]. Grey water recycling is a valuable alternative source of water for no potable uses [5]. A university in Iran used application of trickling filters with plastic media and Lika aggregates in treating grey water [6]. Sand bed filtration, granular activated carbon, and chlorine are used in treated grey water from households [7]. The results were attractive in terms of removing total suspended solids, reducing thirty percent of COD, and decreasing microbial population. Reference [8] studied different types of treatment systems and found that water quality pass through an activated carbon filter after a sand filtration is much better in terms of turbidity and surfactant removal. Leadership in Energy and Environmental Design (LEED), which is one of an acceptable practice in design and build green buildings, demands for water usage reduction of $20 \%$ as prerequisite [9]. If water usage can be reduced further for more than $40 \%$, a

Manuscript received November 15, 2016; revised February 5, 2017.

The authors are with the King Mongkut's University of Technology North Bangkok, Bangkok 10800 Thailand (e-mail: wannawit@gmail.com, sadsada_na@hotmail.com). building can earn a maximum of four credits from water efficiency section. Waste water recycle, therefore, is considered as part of a green building system. If we considered all sources of grey water, it is found that grey water from washbasin is the least polluting grey water [10]. Toilet flushing consumes potable water at the highest percentage in multi-story residential building study in Brazil at the average of $32.8 \%$ [3]. Average domestic water consumption in the UK is currently around 150 litres per head per day [11]. Therefore, using of fresh water for toilet flushing is approximately 49.2 litres per day. Thus, we could save this portion of water by promoting the use of grey water in toilet flushing systems. However, to avoid health risk, grey water should be treated to a higher standard before reusing [12]. A washbasin grey water recycle system for reusing in toilet flushing, therefore, is an objective for this research study. This research compares three water recycle systems and suggest the most suitable one in terms of grey water quality for reuse in toilet flushing systems.

\section{MeTHODOLOGY}

The research was conducted at the King Mongkut's University of Technology North Bangkok. Grey water were collected from all washbasins from 2 nd to 9 th floor of a 9 stories university building. Grey water discharged from all wash basins in the second to ninth floors of the building are averaged for four working days. The averaged values are recorded in every thirty minutes interval from 8:30 to 15:30 and shown in Fig. 1. The daily average discharge is 641 litres. Grey water discharge volumes are estimated roughly by measuring water height increasing in a grey water collection tank. This will allow us to select an appropriate capacity of treatment tanks. In this case, an 800 litres size was selected.

The water were treated in three experiment systems in order to select the most appropriate system. Each system will run for four days. Water is then collected for both before and after treatments for testing in a laboratory. Each system has different components as shown in Table I.

Schematic design of system $A$ is shown in Fig. 2. It receives water from washbasins and collects in a grey water accumulation tank. Then, the water was moved by pump and rested for 24 hours in a sedimentation tank. Water in the tank were pumped to an aeration tank and keep an air pump running for 24 hours. Then, the water was moved by a pump to a sand and carbon filtering tank. Inside this tank, it has 2 layers of materials which are sand and carbon filters. Then, the water was pumped to store in a recycled water accumulation tank for later using in toilet and men urinal flushing systems. 


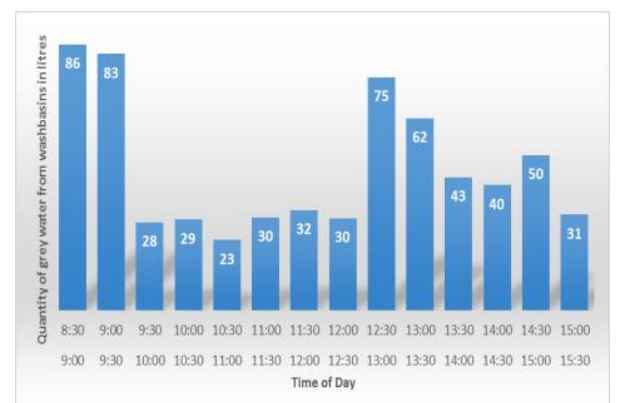

Fig. 1. Grey water discharge in litres varying to time of day.

Fig. 3 and Fig. 4 show schematic design of system B and C. They are similar to system A. However, system B does not have a sedimentation tank, while system $\mathrm{C}$ does not have an aeration tank.

Grey water is collected twice for each system. First, it is collected before treatment at the grey water accumulation tank. Second, it is collected after treatment at the recycled water accumulation tank for a same batch of water. Both water collections were tested in a laboratory according to the American Water Works Association in five parameters interested in this research. They are total suspended solids, fecal coliform bacteria, E.Coli, $\mathrm{BOD}_{5}$, and turbidity.

\section{TABLE I: COMPONENTS OF WATER TREATMENT SYSTEMS}

\begin{tabular}{lllll}
\hline \hline \multirow{2}{*}{ Component Name } & Descriptions & \multicolumn{3}{c}{ System } \\
\cline { 3 - 5 } & & A & B & C \\
\cline { 3 - 5 } $\begin{array}{l}\text { A Grey Water } \\
\text { Accumulation } \\
\text { Tank }\end{array}$ & 800 litres & & & \\
\hline A Sedimentation & 800 litres & & \\
Tank & & & \\
\hline An Aeration Tank & 800 litres & & \\
& with air pump & & \\
\hline A Sand and & $20 \mathrm{~cm}$. in & & \\
Carbon Filter & diameter and & & \\
Tank & $1.50 \mathrm{~m}$. in & & \\
& height & & \\
\hline A Recycled Water & 800 litres & & \\
Accumulation & & & \\
Tank & & & \\
\hline \hline
\end{tabular}

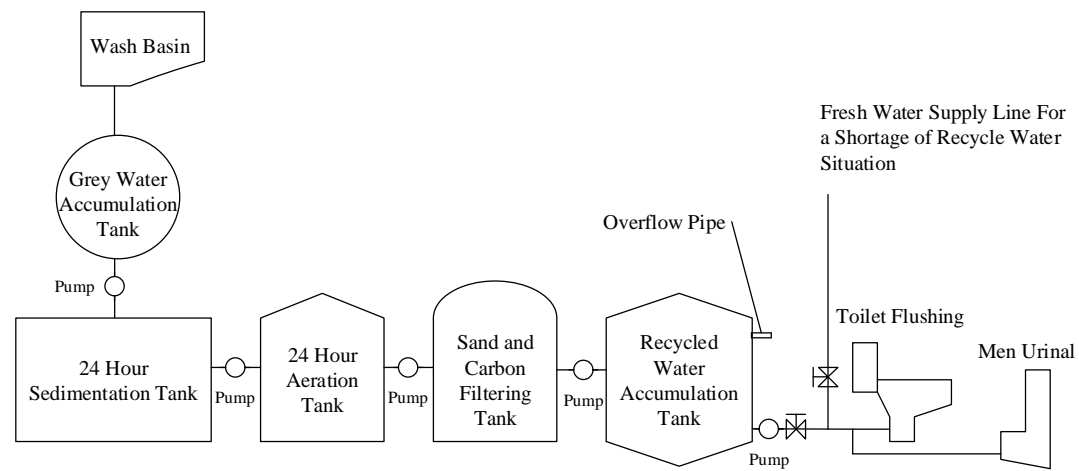

Fig. 2. Schematic flow of grey water from wash basin to reuse in flushing of a treatment system A

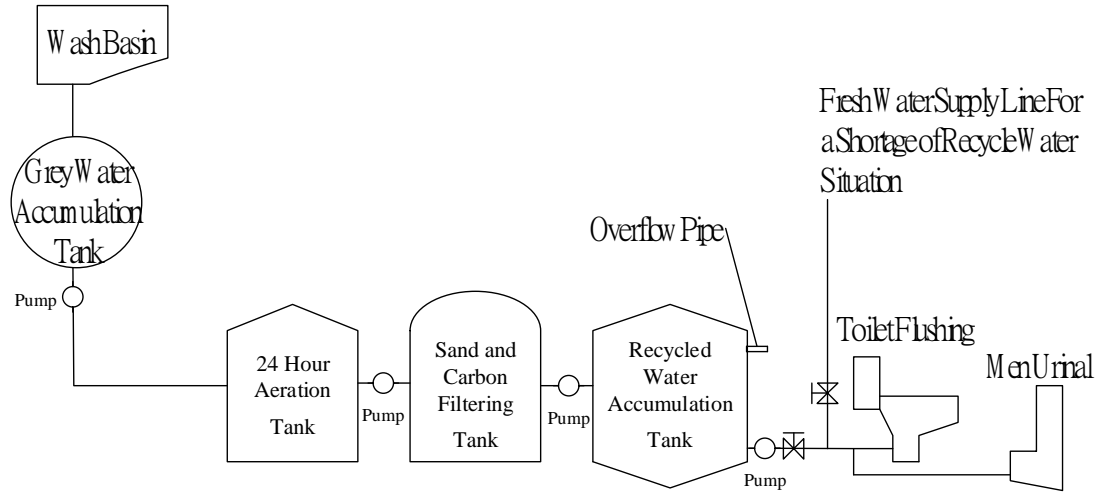

Fig. 3. Schematic flow of grey water from wash basin to reuse in flushing of a treatment system B.

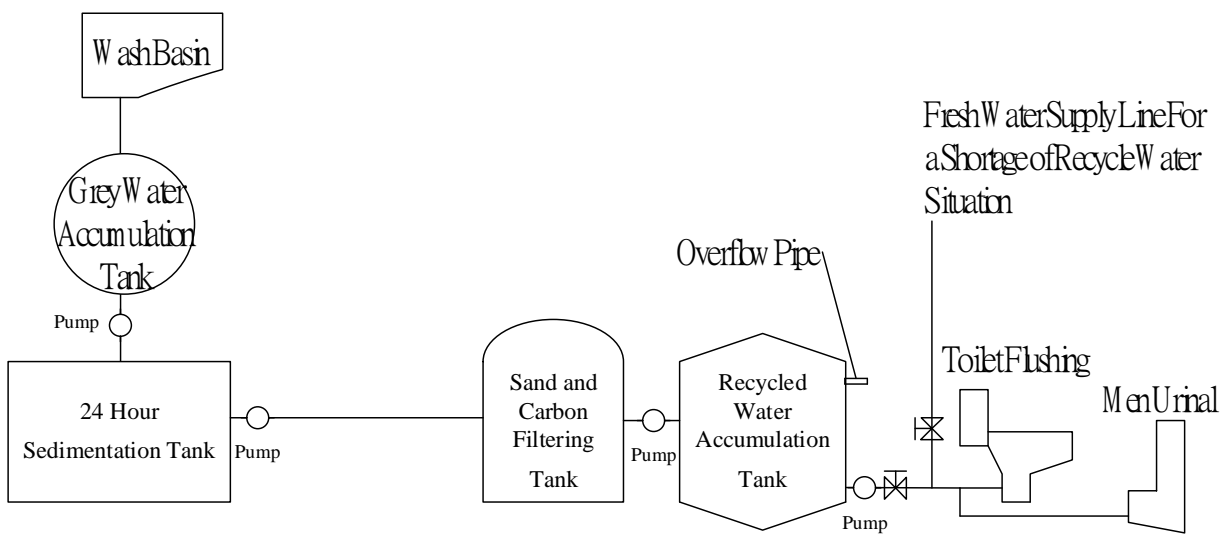

Fig. 4. Schematic flow of grey water from wash basin to reuse in flushing of a treatment system C. 


\section{RESULTS AND DISCUSSIONS}

Table II to Table IV show parameters and water quality for before and after treatment of system A, B, and C, respectively. System $A$ has the highest investment cost at $€ 1,334$ since it is a full system of this research. It can reduce suspended solids good at $90 \%, \mathrm{BOD}_{5}$ for $-10 \%$, and turbidity for $94 \%$, as shown in Table $\mathrm{V}$. The best characteristics of this system is the highest efficiency in decreasing suspended solids and turbidity. However, the $\mathrm{BOD}_{5}$ increases.

System B does not have a 24 hour sedimentation tank. However, it can reduce suspended solids for $90 \%, \mathrm{BOD}_{5}$ for $78 \%$, and turbidity for $75 \%$. It has moderate investment cost at $€ 1,125$. The best characteristics of this system is the highest efficiency in decreasing suspended solids and BOD $_{5}$. The efficiency in reducing the turbidity is moderately good.

System $C$ has the lowest investment cost at $€ 857$. It does not have an aeration tank which is the most expensive equipment in this research. The system can reduce suspended solids well at $82 \%, \mathrm{BOD}_{5}$ for $22 \%$, and turbidity for $66 \%$. However, the fecal coliform bacteria and e.coli are found after the treatment.

System B is selected to operate continuously for one month and observe for water quality. It was found satisfactory by both toilet users and cleaning maids. From interviewing 50 students and 5 maids, $83 \%$ of users gave opinion that water has some colours but acceptable and 69\% of users said that the recycle water liked tap water. Since grey water from wash basin is less polluted comparing to other sources and it can be treated without spending heavy investment on a water recycle system.

TABLE II: GREY WATER QUALITY BEFORE AND AFTER TREATMENT OF SYSTEM A

\begin{tabular}{|c|c|c|c|c|c|c|}
\hline \multirow{2}{*}{ Test Parameter } & \multirow{2}{*}{ Unit } & \multirow{2}{*}{ Test Reference } & \multicolumn{2}{|c|}{ Before Treatment } & \multicolumn{2}{|c|}{$\underline{\text { After Treatment }}$} \\
\hline & & & $\begin{array}{c}\text { Visual } \\
\text { characteristic }\end{array}$ & $\begin{array}{c}\text { Values of each } \\
\text { parameter }\end{array}$ & $\begin{array}{c}\text { Visual } \\
\text { characteristic }\end{array}$ & $\begin{array}{c}\text { Values of each } \\
\text { parameter }\end{array}$ \\
\hline 1. Suspended Solids & $\mathrm{mg} / \mathrm{L}$ & AWWA, 2012 & \multirow{5}{*}{$\begin{array}{c}\text { White colour } \\
\text { water with } \\
\text { turbidity and } \\
\text { suspended solids }\end{array}$} & 31 & \multirow{5}{*}{$\begin{array}{l}\text { Clear with no } \\
\text { colour water and } \\
\text { no suspended } \\
\text { solids }\end{array}$} & 3 \\
\hline $\begin{array}{l}\text { 2. Fecal Coliform } \\
\text { Bacteria }\end{array}$ & MPN/100 mL & AWWA, 2012 & & Not Found & & Not Found \\
\hline 3. E.Coli & $\mathrm{MPN} / 100 \mathrm{~mL}$ & AWWA, 2012 & & Not Found & & Not Found \\
\hline 4. $\mathrm{BOD}_{5}$ & $\mathrm{mg} / \mathrm{L}$ & AWWA, 2012 & & 10 & & 11 \\
\hline 5. Turbidity & NTU & AWWA, 2012 & & 47 & & 3 \\
\hline
\end{tabular}

TABLE III: GREY WATER QUALITY BEFORE AND AFTER TREATMENT OF SYSTEM B

\begin{tabular}{|c|c|c|c|c|c|c|}
\hline \multirow[b]{2}{*}{ Test Parameter } & \multirow[b]{2}{*}{ Unit } & \multirow[b]{2}{*}{ Test Reference } & \multicolumn{2}{|c|}{$\underline{\text { Before Treatment }}$} & \multicolumn{2}{|c|}{$\underline{\text { After Treatment }}$} \\
\hline & & & $\begin{array}{c}\text { Visual } \\
\text { characteristic }\end{array}$ & $\begin{array}{c}\text { Values of each } \\
\text { parameter }\end{array}$ & $\begin{array}{c}\text { Visual } \\
\text { characteristic }\end{array}$ & $\begin{array}{c}\text { Values of each } \\
\text { parameter }\end{array}$ \\
\hline 1. Suspended Solids & $\mathrm{mg} / \mathrm{L}$ & AWWA, 2012 & \multirow{5}{*}{$\begin{array}{c}\text { Yellow clear } \\
\text { water with } \\
\text { suspended solids }\end{array}$} & 20 & \multirow{5}{*}{$\begin{array}{c}\text { Clear with no } \\
\text { colour water } \\
\text { with suspended } \\
\text { solids }\end{array}$} & 2 \\
\hline $\begin{array}{l}\text { 2. Fecal Coliform } \\
\text { Bacteria }\end{array}$ & MPN/100 mL & AWWA, 2012 & & Not Found & & Not Found \\
\hline 3. E.Coli & MPN/100 mL & AWWA, 2012 & & Not Found & & Not Found \\
\hline 4. $\mathrm{BOD}_{5}$ & $\mathrm{mg} / \mathrm{L}$ & AWWA, 2012 & & 18 & & 4 \\
\hline 5. Turbidity & NTU & AWWA, 2012 & & 16 & & 4 \\
\hline
\end{tabular}

\begin{tabular}{|c|c|c|c|c|c|c|}
\hline \multirow{2}{*}{ Test Parameter } & \multirow{2}{*}{ Unit } & \multirow{2}{*}{ Test Reference } & \multicolumn{2}{|c|}{ Before Treatment } & \multicolumn{2}{|c|}{ After Treatment } \\
\hline & & & $\begin{array}{c}\text { Visual } \\
\text { characteristic }\end{array}$ & $\begin{array}{c}\text { Values of each } \\
\text { parameter }\end{array}$ & $\begin{array}{c}\text { Visual } \\
\text { characteristic }\end{array}$ & $\begin{array}{c}\text { Values of each } \\
\text { parameter }\end{array}$ \\
\hline 1. Suspended Solids & $\mathrm{mg} / \mathrm{L}$ & AWWA, 2012 & \multirow{5}{*}{$\begin{array}{l}\text { White colour } \\
\text { water with } \\
\text { turbidity and } \\
\text { suspended solids }\end{array}$} & 22 & \multirow{5}{*}{$\begin{array}{l}\text { Yellow clear } \\
\text { water with } \\
\text { suspended } \\
\text { solids }\end{array}$} & 4 \\
\hline $\begin{array}{l}\text { 2. Fecal Coliform } \\
\text { Bacteria }\end{array}$ & MPN/100 mL & AWWA, 2012 & & Not Found & & 6 \\
\hline 3. E.Coli & $\mathrm{MPN} / 100 \mathrm{~mL}$ & AWWA, 2012 & & Not Found & & 6 \\
\hline 4. $\mathrm{BOD}_{5}$ & $\mathrm{mg} / \mathrm{L}$ & AWWA, 2012 & & 18 & & 14 \\
\hline 5. Turbidity & NTU & AWWA, 2012 & & 49.5 & & 17 \\
\hline
\end{tabular}


TABLE V: TREATMENT EFFECTIVENESS FOR EACH SYSTEM

\begin{tabular}{|l|c|c|c|}
\hline \multirow{2}{*}{$\begin{array}{c}\text { Test } \\
\text { Parameter }\end{array}$} & \multicolumn{3}{|c|}{ Effectiveness of System } \\
\cline { 2 - 4 } & A & B & C \\
\hline $\begin{array}{l}\text { 1. Suspended } \\
\text { Solids }\end{array}$ & $90 \%$ & $90 \%$ & $82 \%$ \\
\hline $\begin{array}{l}\text { 2. Fecal } \\
\text { Coliform } \\
\text { Bacteria }\end{array}$ & Not Found & Not Found & Found \\
\hline 3. E.Coli & Not Found & Not Found & Found \\
\hline 4. BOD 5 & $-10 \%$ & $78 \%$ & $22 \%$ \\
\hline 5. Turbidity & $94 \%$ & $75 \%$ & $66 \%$ \\
\hline
\end{tabular}

\section{CONCLUSION}

From water quality, $\mathrm{BOD}_{5}$ of system $\mathrm{A}$ after the treatment is higher than before treatment. System $\mathrm{C}$ has $\mathrm{BOD}_{5}$ and turbidity values more than generally accepted values in grey water reuse standards. As a result, system $\mathrm{A}$ and $\mathrm{C}$ are not recommended. This research recommends system B for recycle grey water in university buildings and general office buildings which offer same range of grey water properties before treatment as found in this research. Using less fresh water in toilet flushing systems can help saving energy. Fidar et al. confirms that water is relate to energy use and toilet flushing systems have a significant role in reducing water consumption [13]. Thus, by saving water usage in toilet flushing system could help saving our climate and energy and earn a credit according to LEED standard. In conclusion, this research recommends the use of grey water treatment as system B in university buildings to help saving fresh water.

\section{ACKNOWLEDGMENT}

The author wishes to thank the Science and Technology Research Institute at the King Mongkut's University of Technology North Bangkok for funding this research under the grant number KMUTNB-GEN-56-04.

\section{REFERENCES}

[1] S. Liu, D. Butler, F. A. Memon, C. Makropoulos, L. Avery, and B. Jefferson, "Impacts of residence time during storage on potential of water saving for grey water recycling system," Water Research, vol. 44, pp. 267-277, 2010.
[2] B. Jefferson, A. Laine, S. Parsons, T. Stephenson, and S. Judd, "Technologies for domestic wastewater recycling," Urban Water, vol. 1, pp. 285-292, 1999.

[3] E. Ghisi and D. F. Ferreira, "Potential for potable water savings by using rainwater and greywater in a multi-storey residential building in southern Brazil," Building and Environment, vol. 42, pp. 2512-2522, 2007.

[4] M. S. Fountoulakis, N. Markakis, I. Petousi, and T. Manios, "Single house on-site grey water treatment using submerged membrane bioreactor for toilet flushing," Science of the Total Environment, vol. 551-552, pp. 706-711, 2016.

[5] A. Stec and S. Kordana, "Analysis of profitability of rainwater harvesting, gray water recycling and drain water heat recovery systems," Resources, Conservation and Recycling, vol. 105, pp. 84-94, 2015.

[6] N. Shamabadi, H. Bakhtiari, N. Kochakian, and M. Farahani, "The investigation and designing of an onsite grey water treatment systems at Hazrat-e-Masoumeh University, Qom, Iran," Energy Procedia, vol. 74, pp. 1337-1346, 2015

[7] K. Chaillou, C. Gerente, Y. Andres, and D. Wolbert, "Bathroom greywater characterization and potential treatments for reuse," Water Air and Soil Pollution, vol. 215, pp. 31-42, 2011.

[8] M. S. Zipf, I. G. Pinheiro, and M. C. Conegero, "Simplified greywater treatment systems: Slow filters of sand and slate waste followed by granular activated carbon," Journal of Environmental Management, vol. 176, pp. 119-127, 2016.

[9] LEED for New Construction and Major Renovations Rating System, U.S. Green Building Council (USGBC), 2009.

[10] E. Friedler, "Quality of individual domestic greywater streams and its implication for on-site treatment and reuse possibilities," Environmental Technology, vol. 25, pp. 997-1008, 2004.

[11] K. Sutherland, "Wastewater filtration: A future for grey water recycling," Filtration and Separation, pp. 18-21, April 2008.

[12] F. Li, K. Wichmann, and R. Otterpohl, "Review of the technological approaches for grey water treatment and reuses," Science of the Total Environment, vol. 407, pp. 3439-3449, 2009.

[13] A. Fidar, F. A. Memon, and D. Butler, "Environmental implications of water efficient microcomponents in residential buildings," Science of the Total Environment, vol. 408, pp. 5828-5835, 2010.

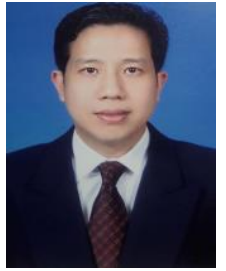

Wannawit Taemthong was born in Bangkok, Thailand in 1971. He received his Ph.D. in civil engineering in 2002 from the University of Michigan, USA. Associate professor Taemthong is currently teaching at the Department of Civil Engineering, King Mongkut's University of Technology North Bangkok. His research fields are sustainable building, indoor air quality, water efficiency in building, and construction management.

Phongphiphat Phenphon received his master degree in civil engineering from the King Mongkut's University of Technology North Bangkok in 2016. He works as a civil engineer in Bangkok now. 